\title{
Proteomics analysis of plasma protein changes in patent ductus arteriosus patients
}

\author{
Cheng $\mathrm{Xu}^{\dagger}$, Xiaoqi Su${ }^{\dagger}$, Yong Chen ${ }^{\dagger}$, Yang Xu, Zhiqi Wang and Xuming $\mathrm{Mo}^{*}$
}

\begin{abstract}
Objective: Patent ductus arteriosus (PDA) is a congenital heart defect with an unclear etiology that occurs commonly among newborns. Adequately understanding the molecular pathogenesis of PDA can contribute to improved treatment and prevention. Plasma proteins may provide evidence to explore the molecular mechanisms of abnormal cardiac development.
\end{abstract}

Methods: Isobaric tags for relative and absolute quantitation (iTRAQ) proteomics technology was used to measure different plasma proteins in PDA patients $(n=4)$ and controls $(n=4)$. The candidate protein was validated by ELISA and Western blot (WB) assays in a larger sample. Validation of the location and expression of this protein was performed in mouse heart sections.

Results: There were three downregulated proteins and eight upregulated proteins identified in the iTRAQ proteomics data. Among these, protein disulfide-isomerase A6 (PDIA6) was further analyzed for validation. The plasma PDIA6 concentrations $(3.2 \pm 0.7 \mathrm{ng} / \mathrm{ml})$ in PDA patients were significantly lower than those in normal controls $(5.8 \pm 1.2 \mathrm{ng} / \mathrm{ml})$. In addition, a WB assay also supported these results. PDIA6 was widely expressed in mouse heart outflow tract on embryonic day 14.5 .

Conclusion: Plasma proteomics profiles suggested novel candidate molecular markers for PDA. The findings may allow development of a new strategy to investigate the mechanism and etiology of PDA.

Keywords: Patent ductus arteriosus, Proteomics, Congenital heart disease

\section{Introduction}

Patent ductus arteriosus (PDA) is a condition in which the ductus arteriosus fails to close after birth; PDA is the second most common congenital heart disease (CHD) [1]. The incidence of PDA has been estimated to be as high as 1 in 200 births [2]. The fetal patency of the ductus arteriosus is controlled by a variety of factors, the most crucial factors are low fetal oxygen tension and cyclooxygenase-mediated metabolites of arachidonic acid

\footnotetext{
*Correspondence: mohsuming15@njmu.edu.cn

${ }^{+}$Cheng Xu, Xiaoqi Su and Yong Chen are joint first authors Department of Cardiothoracic Surgery, Children's Hospital of Nanjing Medical University, 72 Guangzhou Road, Nanjing 210008, China
}

(mainly prostaglandin E2 [PGE2] and prostacyclin [PGI2]) [3, 4]. Circulating PGE2 and PGI2 in the fetus cause ductus arteriosus vasodilatation by interacting with the ductal prostaglandin receptor [5]. After birth, the sudden increase in oxygen tension inhibits the voltage-dependent potassium channel in the cardiac smooth muscle, which leads to an influx of calcium and ductal contraction [6]. PGE2 and PGI2 levels decline due to metabolic lung function and elimination of their placental origin. The medial smooth muscle fibers in the heart lead to thickening of the wall, obliteration of the lumen, and shortening of the ductus arteriosus. Functional closure usually occurs within 24 to $48 \mathrm{~h}$ of term

(c) The Author(s). 2020 Open Access This article is licensed under a Creative Commons Attribution 4.0 International License, which permits use, sharing, adaptation, distribution and reproduction in any medium or format, as long as you give appropriate credit to the original author(s) and the source, provide a link to the Creative Commons licence, and indicate if changes were made. The images or other third party material in this article are included in the article's Creative Commons licence, unless indicated otherwise in a credit line to the material. If material is not included in the article's Creative Commons licence and your intended use is not permitted by statutory regulation or exceeds the permitted use, you will need to obtain permission directly from the copyright holder. To view a copy of this licence, visit http://creativecommons.org/licenses/by/4.0/ The Creative Commons Public Domain Dedication waiver (http://creativecommons.org/publicdomain/zero/1.0/) applies to the data made available in this article, unless otherwise stated in a credit line to the data. 
birth. Over the next 2 to 3 weeks, intimal folding, destruction and proliferation lead to fibrosis and a permanent seal [7]. The resulting fibrous band has no lumen and is an arterial ligament. Genetic and environmental factors may be involved in the pathogenesis of PDA $[8,9]$. However, the factors underlying continuous patency of the ductus arteriosus are not fully understood.

Proteomics may play an increasingly important role in identifying biomarkers and novel pathogenic factors. Proteomics analysis of body fluids (e.g., serum and urine) is a promising tool to better understand the etiology of vascular abnormities and the pathogenesis of CHD and to explore disease markers [10-12]. Several studies have been conducted using two-dimensional electrophoresis and mass spectrometry methods to identify plasmabased biomarkers of CHD subtypes (e.g., ventricular septal defect (VSD), tetralogy of Fallot (TOF)) [13, 14]. Moreover, because proteins directly execute physiological functions, proteomics technology may be able to identify novel pathogenic factors better than genomics and metabonomics $[15,16]$. However, plasma protein biomarkers for PDA, which is the second most common form of CHD, remain unknown.

Recently, isobaric tags for relative and absolute quantitation (iTRAQ) has been applied in many research fields $[17,18]$. The main advantage of iTRAQ is that it can label peptides whose sites may otherwise not be accessible to other reagents at the protein level [19]. In the present study, liquid chromatography-tandem mass spectrometry (LC-MS-MS) coupled with iTRAQ was performed to quantify plasma proteins from patients with PDA and healthy controls in order to explore differential protein expression and its relationship to the pathogenesis of PDA.

\section{Materials and methods}

\section{Study population and sample collection}

We collected blood samples from control individuals and PDA patients preoperatively after obtaining approval from the Ethics Committee of the Children's Hospital of Nanjing Medical University in Nanjing, China (No. 201801146-1). The control subjects were age- and gender-matched, and all subjects were the same ethnicity to reduce bias. A total of 100 controls and 100 PDA patients were included in our study. The diagnoses of all patients in the present study were confirmed by preoperative echocardiography and corrective surgery. We excluded patients with complex CHDs and complications. The legal guardian of each participant provided informed consent. The $5 \mathrm{~mL}$ whole blood sample of each control or patient was centrifuged at $3000 \mathrm{~g}, 4{ }^{\circ} \mathrm{C}$ for 10 min. The supernatant serum samples were stored immediately at $-80^{\circ} \mathrm{C}$ for subsequent detection.

\section{Protein extraction, digestion and labeling}

Before detection, we depleted the most abundant proteins in all eight serum samples (4 vs 4 ) by using the ProteoMiner protein enrichment kit (Bio-Rad Laboratories, Inc.). A total of $100 \mu \mathrm{g}$ of protein from each sample that was 5 times volume diluted with triethylammonium bicarbonate was used for further tryptic digestion. The digestion process was performed by adding trypsin (Promega, Madison, WI, USA) to the samples with an enzyme-protein ratio of $1: 50(\mathrm{w} / \mathrm{w})$, the mixture was then stored at $37^{\circ} \mathrm{C}$ overnight. One volume of $0.1 \%$ formic acid (FA) solution (enzymatic hydrolysate) was added to acidify the proteins to peptides. Then, the peptides were desalted with a Strata-X C18 column. According to the manufacturer's protocol, iTRAQ 8-plex kits (AB Sciex Inc., Framingham, MA, USA) were used to label the peptides. Then, a high-performance liquid chromatography (HPLC) system (Thermo DINOEX Ultimate 3000 BioRS) with a Durashell C18 $(5 \mu \mathrm{m}, 100 \AA, 4.6 \times 250 \mathrm{~mm})$ was used to fractionate the labeled samples.

\section{Liquid chromatography-electrospray ionization-tandem mass spectrometry LC-ESI-MS/MS analysis}

A TripleTOF 5600+ mass spectrometer and an Eksigent nanoLC System (SCIEX, USA) were used to dissolve each fraction with $2 \%$ acetonitrile/0.1\% FA. Survey scans were acquired at $250 \mathrm{~ms}$, and 30 product ion scans were gathered at $100 \mathrm{~ms} /$ per scan for information-dependent acquisition (IDA). The range from 350 to $1500 \mathrm{~m} / \mathrm{z}$ indicated MS1 spectra, and the range from 100 to $1500 \mathrm{~m} / \mathrm{z}$ indicated MS2 spectra. We excluded precursor ions for $15 \mathrm{~s}$ reselection.

\section{Enzyme-linked immunosorbent assay (ELISA)}

We used an ELISA method to measure protein disulfideisomerase A6 (PDIA6) levels. A commercial ELISA kit was purchased from MyBioSource (San Diego, USA). The lowest detection limit of the assay was $0.1 \mathrm{ng} / \mathrm{ml}$ with a coefficient of variation for the quality control specimens of $<10 \%$.

\section{Western blot (WB)}

Sodium dodecyl sulfate-polyacrylamide gel electrophoresis (SDS-PAGE) was conducted to separate the total proteins from the subjects' serum samples; subsequently, the proteins were transferred to polyvinylidene fluoride membranes (Millipore, Billerica, MA, USA). The following antibody was used for the Western blot (WB) assay: anti-PDIA6 antibody (Abcam, 1:1000). Enhanced chemiluminescence (Millipore, Billerica, MA, USA) was used to test for immune complexes. Anti-albumin (Cell Signaling Technology, 1:1000) was used as an internal control. The band was semiquantified using Image Lab software (Bio-Rad laboratories, Hercules, CA, USA). Each assay was performed at least three times. 
Table 1 Characteristics of the study subjects

\begin{tabular}{|c|c|c|c|c|c|c|}
\hline & Groups & No. & Boy & Girl & Age (month) & Weight $(\mathrm{kg})$ \\
\hline \multirow[t]{2}{*}{ iTRAQ } & Controls & 4 & $2(50 \%)$ & $2(50 \%)$ & $27.3 \pm 7.5$ & $11.3 \pm 1.3$ \\
\hline & PDA & 4 & $2(50 \%)$ & $2(50 \%)$ & $29.5 \pm 9.8$ & $11.3 \pm 2.3$ \\
\hline \multirow[t]{2}{*}{ ELISA } & Controls & 96 & $34(35.4 \%)$ & 62 (64.6\%) & $24.9 \pm 27.1$ & $10.7 \pm 4.3$ \\
\hline & PDA & 96 & 35 (36.5\%) & 61 (63.5\%) & $24.1 \pm 25.6$ & $10.4 \pm 5.7$ \\
\hline
\end{tabular}

iTRAQ Isobaric tag for relative and absolute quantitation; ELISA Enzyme-linked immunosorbent assay; PDA Patent ductus arteriosus

$\mathrm{N}(\%)$, mean \pm standard deviation

\section{Mice}

All animal experiments were performed with the approval of the Institutional Animal Care and Use Committee of Nanjing Medical University. Six C57BL6 mice (from Shanghai SLAC Laboratory Animal Co., Ltd. Shanghai, China) were fed ad libitum diet and water and housed with a 12 -h light/dark cycle at $22^{\circ} \mathrm{C}$. The mice were sacrificed at embryonic day 14.5 (E14.5).

\section{Immunofluorescence (IF)}

Frozen sections of cardiac tissue were processed for immunofluorescence (IF) with the primary antibody to PDIA6 (1:500 dilution). Then, fluorescein isothiocyanate (FITC) dye was used to stain for PDIA6, and 4',6-diamidino-2phenylindole (DAPI) was used to stain nuclei. Cardiac sections were evaluated with a confocal laser scanning microscope (CLSM SP2; Leica, Nidau, Switzerland).

\section{Data analysis}

ProteinPilot 4.5 Software (July 2012; AB Sciex) was used to identify and quantify protein levels. We searched for mass spectrometry spectra in the UniProtKB/Swiss-Prot Homo sapiens protein database (20,240 proteins, updated in May 2018). The parameters for the search strategy were set as follows: the instrument was TripleTOF 5600 with iTRAQ quantification and cysteine modified with iodoacetamide; the biological modifications included ID focus, trypsin digestion, and quantification; and bias correction and background correction were checked for protein quantification and normalization. Statistical significance of differences in protein expression levels between the two groups was determined by Student's $t$ test, and multiple comparisons were corrected for with the Benjamini and Hochberg method. To identify significant changes, the threshold was set at a two-fold change with a corrected $p$ value less than 0.05 . ELISA and WB data were analyzed with the Mann-Whitney U test.

\section{Results}

\section{Participant characteristics}

The gender distribution, mean age and weight are presented in Table 1 . In the iTRAQ analysis, gender was matched, and the mean \pm standard deviation of age was $6.3 \pm 2.0$ months in control participants and $6.8 \pm 2.1$ months in PDA patients. In the ELISA analysis, the gender distribution and mean age were similar between two

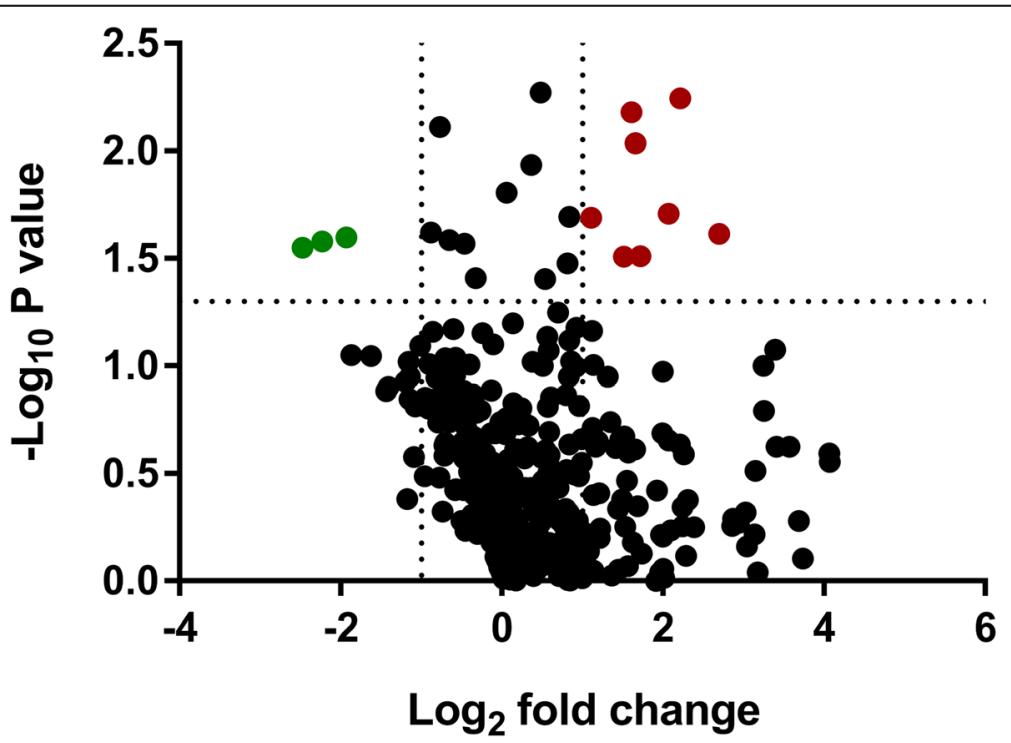

Fig. 1 Volcano plot of proteins detected by iTRAQ among PDA patients and controls. The green dot represents decreased protein levels $(p<0.05$ and fold-change $<0.5)$, and the red dot represents increased protein levels $(p<0.05$ and fold-change $>2.0)$ 
Table 2 Differential proteins expressed in two groups with PDA compared to the control

\begin{tabular}{|c|c|c|c|c|}
\hline Accession & Abbreviation & Protein Name & $\begin{array}{l}\text { PDA vs Control } \\
\text { Fold change }\end{array}$ & $P$ value \\
\hline P01764 & HV323 & Immunoglobulin heavy variable 3-23 & 4.64 & 0.005685 \\
\hline P12259 & FA5 & Coagulation factor $V$ & 3.05 & 0.006601 \\
\hline A2NJV5 & KV229 & Immunoglobulin kappa variable 2-29 & 3.15 & 0.009199 \\
\hline P01699 & LV144 & Immunoglobulin lambda variable 1-44 & 4.19 & 0.01957 \\
\hline P67936 & TPM4 & Tropomyosin alpha-4 chain & 2.16 & 0.020354 \\
\hline Q08380 & LG3BP & Galectin-3-binding protein & 6.49 & 0.024261 \\
\hline P01833 & PIGR & Polymeric immunoglobulin receptor & 3.29 & 0.030769 \\
\hline P01700 & LV147 & Immunoglobulin lambda variable 1-47 & 2.86 & 0.030875 \\
\hline P02765 & FETUA & Alpha-2-HS-glycoprotein & 0.26 & 0.025121 \\
\hline Q15084 & PDIA6 & Protein disulfide-isomerase A6 & 0.21 & 0.02597 \\
\hline P00736 & C1R & Complement $\mathrm{C} 1 \mathrm{r}$ subcomponent & 0.18 & 0.028103 \\
\hline
\end{tabular}

groups. No significant differences were found between the PDA and control groups in iTRAQ proteomics and ELISA analyses.

\section{Proteomics analysis}

In this part of study, 4 plasma samples from healthy control participants and 4 plasma samples from PDA patients were collected and compared. Three proteins were significantly downregulation $(p<0.05$ and $<0.5$-fold change), and eight proteins were significantly upregulated ( $p<0.05$ and $>2.0$-fold change) (Fig. 1). The details of the different protein expression levels are listed in Table 2.

\section{ELISA and WB}

To validate the proteomics data, we further determined PDIA6 levels with ELISA in a larger number of samples ( $n=96$ PDA patients and $n=96$ controls). The plasma PDIA6 concentrations in healthy controls and PDA patients were $5.8 \pm 1.2 \mathrm{ng} / \mathrm{ml}$ and $3.2 \pm 0.7 \mathrm{ng} / \mathrm{ml}$, respectively (Fig. 2a). Importantly, the PDIA6 protein expression was confirmed to be significantly decreased in PDA patients compared with that in the controls $(p=$ 0.004 for the Mann-Whitney U test). In addition, we also performed a WB assay to confirm the proteomics data. The plasma protein expression of PDIA6 in 4 selected PDA patients was remarkably decreased compared with that in the controls (Fig. 2b).

\section{Conservation comparisons of amino acids and IF}

We evaluated PDIA6 expression in mouse cardiac tissue on PO because the samples that were previously evaluated were from circulating plasma, not tissue. First, we evaluated amino acid conservation between human, mouse and rat tissues. The amino acid sequence homology of these three species was 95\% (Supplemental Figure 1). Next, we used a mouse model to represent a human model. Figure 3 shows that PDIA6 was widely expressed in the mouse hearts in E14.5.

\section{Discussion}

In the present study, we explored changes in protein expression in plasma samples from PDA patients with iTRAQ proteomics technology. We discovered that circulating PDIA6 was downregulated in PDA patients compared with in healthy controls. PDIA6 was expressed in the ductus arteriosus of mice on P0 and may play a role in the pathogenesis of PDA.
A

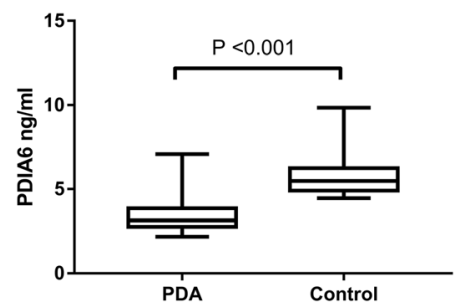

B

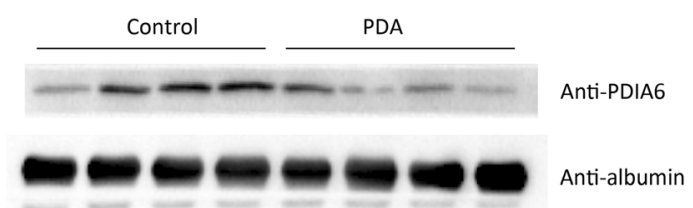

Fig. 2 PDIA6 protein was measured by ELISA and WB in PDA patients and controls. a, ELISA was used to examine each subject's plasma levels of PDIA6. $N=96$ PDA patients and $N=96$ controls. b, WB was performed to compare PDIA6 expression in plasma samples from PDA patients and controls. ELISA and WB assays were both performed three times 


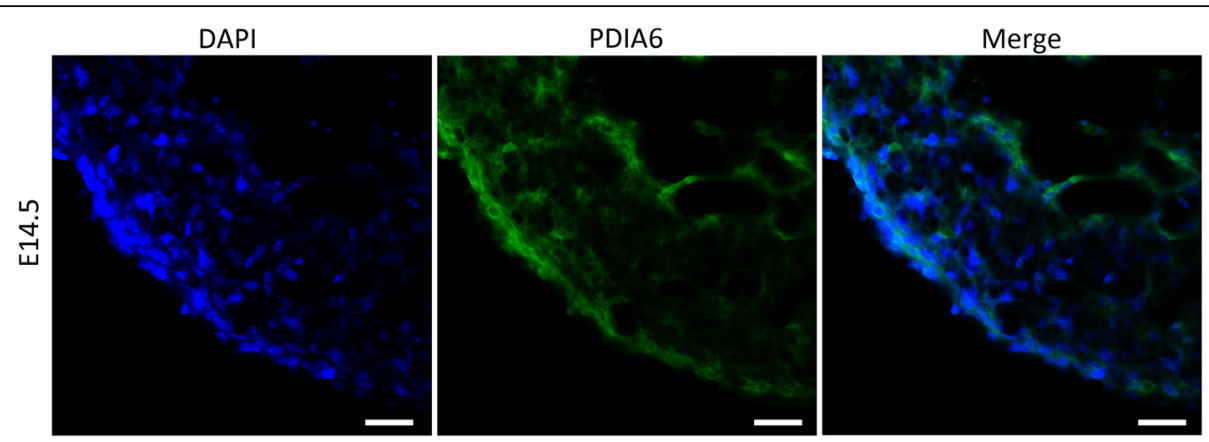

Fig. 3 Representative IF picture showing the location and expression of PDIA6 in mouse heart tissue on E14.5. Blue indicates the nucleus, and green indicates PDIA6. The experiment was performed three times. Scar bar $=100 \mu \mathrm{m}$

Previously published studies on CHD (Table 3) have mainly focused on VSD and TOF subtypes of CHD. In the VSD subtype, haptoglobin, amyloid P component, carbamoyl-phosphate synthase I, and ficolin-3 have been found to be significantly decreased in patients. Haptoglobin, amyloid P component, and ficolin-3 have been reported to be associated with innate immune system function $[20,21]$, suggesting that CHD patients have attenuated immune function. Carbamoyl-phosphate synthase I plays a role in the urea cycle and in endogenous nitric oxide production [22]. Differential protein expression has not been reported in the PDA subtype of CHD before. We found that ELISA methods were used to confirm high-throughput results in most previous articles. We also performed WB experiments in the present study. Disparate differential protein expression results were discovered in our study and in other studies. We speculate that different populations, proteomics technology, and disease subtypes evaluated may be the reason for these differences. The present research revealed an association between differential protein expression and PDA; however, in vitro and in vivo models may provide more evidence to demonstrate a causal relationship.

PDIA6 is located in the eukaryotic ER and functions as an isomerase and molecular chaperone [23]. Several reports using loss-of-function assays have shown that PDIA6 plays a role in unfolded protein response signaling [24] and acts as a negative modulator of both Ser/Thr protein kinase inositol-requiring enzyme-1 and protein kinase RNA-like ER kinase [25]. In addition, PDIA6 maintains calcium homeostasis in the ER [26]. The ER can affect cardiac development and function in the following ways: a) acting in $\mathrm{Ca}^{2+}$-dependent pathways; b) playing a role in folding proteins; c) targeting membrane-bound and secretory proteins; and d) responding to cellular stress events, such as hypoxic conditions [27]. Several ER genes are activated during the early stages of cardiogenesis, for example calreticulin-1 [28], Grp94 [29], and BiP [30], suggesting the potential function of the ER in embryonic cardiac development. Vekich et al. found that PDIA6 could protect cardiomyocytes by interacting with activating transcription factor 6 [31]. However, the exact roles of PDIA6 in cardiac development remain unclear.

There are several limitations in our study. First, although the number of PDA patients included was large, a multicenter study may yield more convincing results. Additionally, examination indicators such as echocardiography were not obtained in this study, and the associations between altered protein expression and clinical parameters may reveal underlying pathogenic mechanisms. In

Table 3 Published proteomics study in congenital heart disease (CHD)

\begin{tabular}{|c|c|c|c|c|c|c|c|}
\hline Sample source & Subtype of CHD & $\begin{array}{l}\text { Proteomics } \\
\text { technology }\end{array}$ & Confirm method & Compare & Up & Down & $\begin{array}{l}\text { References } \\
\text { (PMID) }\end{array}$ \\
\hline Children plasma & VSD & $2 \mathrm{DE}$ & ELISA & VSD vs. control & Orosomucoid 2 & $\begin{array}{l}\text { Haptoglobin, amyloid } \\
\text { P-component }\end{array}$ & $25,914,298$ \\
\hline Children plasma & $\begin{array}{l}\text { VSD, } \\
\text { ASD }\end{array}$ & iTRAQ & ELISA & $\begin{array}{l}\text { VSD vs. control, } \\
\text { ASD vs. control }\end{array}$ & N/A & $\begin{array}{l}\text { Carbamoyl-phosphate } \\
\text { synthase I, } \\
\text { Complement Factor } \\
\text { H-related Protein } 2\end{array}$ & $27,886,187$ \\
\hline Children plasma & TOF & $2 \mathrm{DE}$ & ELISA & TOF vs. control & N/A & $\begin{array}{l}\text { Gelsolin, } \\
\text { Ficolin-3 }\end{array}$ & $24,565,402$ \\
\hline Children plasma & VSD & $2 \mathrm{DE}$ & ELISA & VSD vs. control & N/A & Ficolin-3 & $24,565,402$ \\
\hline Maternal serum & TOF & LC/MS & N/A & TOF vs. control & N/A & N/A & $28,598,000$ \\
\hline
\end{tabular}

TOF Tetralogy of Fallot; VSD Ventricular septal defect; ASD Atrial septal defect; $2 D E$ Two-dimensional electrophoresis; LC/MS Liquid chromatography/mass spectrometry; ELISA Enzyme-Linked Immunosorbent Assay; N/A Not applicable 
addition, long- term follow-up data may further elucidate the roles of PDIA6. Finally, because the study was a crosssectional study, it was not possible to determine whether PDA led to reduced plasma PDIA6 concentrations or whether decreased PDIA6 concentrations induced PDA progression. Furthermore, we will use a loss-of-function method in vitro and in vivo to explore whether PDIA6 plays a role in the pathogenesis and molecular mechanisms of PDA.

\section{Conclusion}

In conclusion, we identified, for the first time, found alterations of 11 differential proteins by using the iTRAQ in the plasma of patients with PDA and controls. Importantly, our result demonstrated that the level of plasma PDIA6 was downregulated in patients with PDA, which may partially explain the roles of PDIA6 in cardiac development. The altered PDIA6 we identified may have potential clinical implications for PDA treatment and provide evidence regarding the etiology and molecular mechanism of PDA.

\section{Supplementary information}

Supplementary information accompanies this paper at https://doi.org/10. 1186/s13052-020-00831-6.

\section{Additional file 1.}

\section{Acknowledgements}

Not applicable.

\begin{abstract}
Authors' contributions
C. X., X.Q.S. and Y. C. performed research, analyzed data, and wrote the manuscript. Y. X. and Z.Q.W. contributed patient samples and data. Q.W.Z. and X.M.M. performed research and critically revised the manuscript. The author(s) read and approved the final manuscript.
\end{abstract}

\section{Funding}

This work was supported by funding from the National Natural Science Foundation of China (81900281); the National Key Research and Development Program of China (2017YFC1308105, 2016YFC1101001); the China Postdoctoral Science Foundation (2018 M630585); the Key Project of Science and Technology Development Fund of Nanjing Medical University (2017NJMUZD060); a Nanjing Medical University School Project (NMUC2018012A); and a Key Project supported by the Medical Science and Technology Development Foundation, Nanjing Department of Health (YKK18139).

\section{Availability of data and materials}

All data analysed during this study are included in this published article and its supplementary information files.

\section{Ethics approval and consent to participate}

Study approval and ethical clearance was obtained from the Children's Hospital of Nanjing Medical University. Written consent was obtained from the guardian of the child prior to data collection.

\section{Consent for publication}

Not applicable.

\section{Competing interests}

The authors declare that they have no competing interests
Received: 6 November 2019 Accepted: 11 May 2020

Published online: 19 May 2020

\section{References}

1. Schneider DJ, Moore JW. Patent ductus arteriosus. Circulation. 2006;114(17): 1873-82.

2. Lloyd TR, Beekman RH 3rd. Clinically silent patent ductus arteriosus. Am Heart J. 1994;127(6):1664-5.

3. Coceani F, Olley PM. The response of the ductus arteriosus to prostaglandins. Can J Physiol Pharmacol. 1973;51(3):220-5.

4. Hung YC, Yeh JL, Hsu JH. Molecular mechanisms for regulating postnatal Ductus Arteriosus closure. Int J Mol Sci. 2018;19(7).

5. Michelakis E, Rebeyka I, Bateson J, Olley P, Puttagunta L, Archer S. Voltagegated potassium channels in human ductus arteriosus. Lancet. 2000; 356(9224):134-7.

6. Leonhardt A, Glaser A, Wegmann M, Schranz D, Seyberth H, Nusing R. Expression of prostanoid receptors in human ductus arteriosus. $\mathrm{Br} J$ Pharmacol. 2003;138(4):655-9.

7. Fay FS, Cooke PH. Guinea pig ductus arteriosus. II. Irreversible closure after birth. Am J Physiol. 1972:222(4):841-9.

8. Hajj H, Dagle JM. Genetics of patent ductus arteriosus susceptibility and treatment. Semin Perinatol. 2012;36(2):98-104

9. Wang X, Li P, Chen S, Xi L, Guo Y, Guo A, Sun K. Influence of genes and the environment in familial congenital heart defects. Mol Med Rep. 2014;9(2): 695-700.

10. Filip S, Pontillo C, Peter Schanstra J, Vlahou A, Mischak H, Klein J. Urinary proteomics and molecular determinants of chronic kidney disease: possible link to proteases. Expert Rev Proteomics. 2014;11(5):535-48.

11. Huang L, Li L, Yang T, Li W, Song L, Meng X, Gu Q, Xiong C, He J. Transgelin as a potential target in the reversibility of pulmonary arterial hypertension secondary to congenital heart disease. J Cell Mol Med. 2018;22(12):6249-61.

12. Dorr KM, Conlon FL. Proteomic-based approaches to cardiac development and disease. Curr Opin Chem Biol. 2019:48:150-7.

13. Xuan C, Gao G, Yang Q, Wang XL, Liu ZG, Liu XC, He GW. Proteomic study reveals plasma protein changes in congenital heart diseases. Ann Thorac Surg. 2014;97(4):1414-9.

14. Zhang X, Wang K, Yang Q, Wang J, Xuan C, Liu XC, Liu ZG, He GW. Acute phase proteins altered in the plasma of patients with congenital ventricular septal defect. Proteomics Clin Appl. 2015;9(11-12):1087-96.

15. Thomford NE, Dzobo K, Yao NA, Chimusa E, Evans J, Okai E, Kruszka P, Muenke M, Awandare G, Wonkam A, Dandara C. Genomics and Epigenomics of congenital heart defects: expert review and lessons learned in Africa. OMICS. 2018:22(5):301-21.

16. Chen L, Guan J, Wei Q, Yuan Z, Zhang M. Potential role of "omics" technique in prenatal diagnosis of congenital heart defects, Clinica chimica acta. Int J Clin Chem. 2018;482:185-90.

17. Moulder R, Bhosale SD, Goodlett DR, Lahesmaa R. Analysis of the plasma proteome using ITRAQ and TMT-based isobaric labeling. Mass Spectrom Rev. 2018;37(5):583-606.

18. Wang FS, Dong SR, Zhang HY, Wang SY. Putative model based on ITRAQ proteomics for Spirulina morphogenesis mechanisms. J Proteome. 2018;171: 73-80.

19. Wu WW, Wang G, Baek SJ, Shen RF. Comparative study of three proteomic quantitative methods, DIGE, CICAT, and iTRAQ, using 2D gel- or LC-MALDI TOF/TOF. J Proteome Res. 2006;5(3):651-8.

20. Shen H, Song Y, Colangelo CM, Wu T, Bruce C, Scabia G, Galan A, Maffei M, Goldstein DR. Haptoglobin activates innate immunity to enhance acute transplant rejection in mice. J Clin Invest. 2012;122(1):383-7.

21. Cox N, Pilling D, Gomer RH. Serum amyloid P: a systemic regulator of the innate immune response. J Leukoc Biol. 2014;96(5):739-43.

22. Summar ML, Gainer JV, Pretorius M, Malave H, Harris S, Hall LD, Weisberg A, Vaughan DE, Christman BW, Brown NJ. Relationship between carbamoylphosphate synthetase genotype and systemic vascular function. Hypertension. 2004;43(2):186-91.

23. Hatahet F, Ruddock LW. Protein disulfide isomerase: a critical evaluation of its function in disulfide bond formation. Antioxid Redox Signal. 2009;11(11): 2807-50.

24. Eletto D, Eletto D, Dersh D, Gidalevitz T, Argon Y. Protein disulfide isomerase A6 controls the decay of IRE1alpha signaling via disulfide-dependent association. Mol Cell. 2014;53(4):562-76. 
25. Eletto D, Eletto D, Boyle S, Argon Y. PDIA6 regulates insulin secretion by selectively inhibiting the RIDD activity of IRE1. FASEB J. 2016;30(2):653-65.

26. Groenendyk J, Peng Z, Dudek E, Fan X, Mizianty MJ, Dufey E, Urra H, Sepulveda D, Rojas-Rivera D, Lim Y, Kim DH, Baretta K, Srikanth S, Gwack Y, Ahnn J, Kaufman RJ, Lee SK, Hetz C, Kurgan L, Michalak M. Interplay between the oxidoreductase PDIA6 and microRNA-322 controls the response to disrupted endoplasmic reticulum calcium homeostasis. Sci Signal. 2014;7(329):ra54.

27. Prins D, Michalak M. Endoplasmic reticulum proteins in cardiac development and dysfunction. Can J Physiol Pharmacol. 2009;87(6):419-25

28. Qiu Y, Michalak M. Transcriptional control of the calreticulin gene in health and disease. Int J Biochem Cell Biol. 2009;41(3):531-8.

29. Wanderling S, Simen BB, Ostrovsky O, Ahmed NT, Vogen SM, Gidalevitz T, Argon Y. GRP94 is essential for mesoderm induction and muscle development because it regulates insulin-like growth factor secretion. Mol Biol Cell. 2007;18(10):3764-75.

30. Mao C, Tai WC, Bai Y, Poizat C, Lee AS. In vivo regulation of Grp78/BiP transcription in the embryonic heart: role of the endoplasmic reticulum stress response element and GATA-4. J Biol Chem. 2006;281(13):8877-87.

31. Vekich JA, Belmont PJ, Thuerauf DJ, Glembotski CC. Protein disulfide isomerase-associated 6 is an ATF6-inducible ER stress response protein that protects cardiac myocytes from ischemia/reperfusion-mediated cell death. J Mol Cell Cardiol. 2012;53(2):259-67.

\section{Publisher's Note}

Springer Nature remains neutral with regard to jurisdictional claims in published maps and institutional affiliations.

Ready to submit your research? Choose BMC and benefit from:

- fast, convenient online submission

- thorough peer review by experienced researchers in your field

- rapid publication on acceptance

- support for research data, including large and complex data types

- gold Open Access which fosters wider collaboration and increased citations

- maximum visibility for your research: over $100 \mathrm{M}$ website views per year

At BMC, research is always in progress.

Learn more biomedcentral.com/submissions 